Case Report

\title{
Hysterectomy to the Unicornuate Uterus Suffering of Hematometra
}

\author{
Histerektomi pada Unicornuate Uterus dengan Hematometra
}

\author{
Cepi T Pramayadi, Imma Nurliana, Erliana Fani \\ Department of Obstetrics and Gynecology \\ Faculty of Medicine Universitas Indonesia/ \\ Dr. Cipto Mangunkusumo Hospital \\ Jakarta
}

\begin{abstract}
Objective: Unicornuate uterus with rudimentary cavity is an extremely rare Mullerian duct anomaly. It is frequently misdiagnosed or under treated, since women who suffer from this condition tend to be asymptomatic. We aimed to report this interesting case and review the available background literature.

Methods: Case report.

Case: A thirty two-year-old nulligravid woman was presented with severe abdominal pain. Laparoscopic surgery demonstrated unicornuate uterus with arudimentary cavity and hematometra. Partial hysterectomy was conducted to the right rudimentary uterus.

Conclusion: Thorough diagnosis is essential to prevent the complications of unicornuate uterus. Unicornuate uterus with rudimentary cavity is associated with increased rate of pregnancy complications such as preterm labor and fetal malpresentation. Pregnancy can also occurred on the rudimentary cavity and leads to recurrent pregnancy loss. Laparoscopy is essential for confirmatory diagnosis. Surgical intervention should be considered as the first line therapy to avoid associated morbidity.

[Indones J Obstet Gynecol 2017; 5-4: 246-249]
\end{abstract}

Keywords: hematometra, hysterectomy, unicornuate uterus

\begin{abstract}
Abstrak
Tujuan: Melaporkan kasus kelainan bawaan pada uterus dan membahas literatur terkait. Unicornuate uterus dengan rongga rudimenter merupakan kasus yang sangat jarang pada kelainan duktus Mullerian. Kasus ini sering tidak terdiagnosis sehingga tidak mendapatkan penanganan yang sesuai terutama dikarenakan sebagian besar pasien tidak memiliki keluhan.

Metode: Laporan kasus.

Kasus: Tiga puluh dua tahun nulligravida datang dengan keluhan utama nyeri hebat pada perut bagian bawah. Laparoskopi menunjukkan unicornuate uterus dengan rongga rudimenter dan hematometra sisi kanan. Histerektomi parsial dilakukan pada uterus rudimenter tersebut.

Kesimpulan: Diagnosis menyeluruh diperlukan untuk mencegah komplikasi pada unicornuate uterus. Komplikasi yang berhubungan dengan unicornuate uterus antara lain kelahiran prematur dan malpresentasi. Kehamilan pada kavum yang rudimenter juga dapat terjadi dan mengakibatkan gagalnya kehamilan. Laparoskopi adalah alat utama untuk memastikan diagnosis. Intervensi bedah sebaiknya menjadi lini pertama untuk mencegah morbiditas.
\end{abstract}

[Maj Obstet Ginekol Indones 2017; 5-4: 246-249]

Kata kunci: hematometra, histerektomi, unicornuate uterus

Correspondence: Cepi T Pramayadi. cteguh@yahoo.com

\section{INTRODUCTION}

Congenital uterine anomalies were found in 5.5\% of unselected population, $8.0 \%$ of infertile women, and $13.3 \%$ in women with a history of miscarriage, and $24.5 \%$ in those with miscarriage and infertility. ${ }^{1-3}$ Unicornuate uterus is a rare congenital anomaly of the female reproductive system, resulting from partial development of one-out-of-the-two Mullerian ducts. ${ }^{1}$ It causes numerous gynaecologic and obstetrical complications ${ }^{2}$, and it is also associated with increased rate of preterm birth, fetal malpresentation and gestation in the rudimentary cavity. ${ }^{2}$ The European's Society of
Human Reproduction and Embryology (ESHRE)/ European's Society for Gynaecological Endoscopy (ESGE) has adopted a new classification system ${ }^{2}$, in which according to this new system, unicornuate uterus (U4) incorporates all cases of unilateral formed uterus, and the contralateral part could be either incompletely formed or absent (Figure 1).,2,5 Unicornuate uterus with a rudimentary (functional) cavity (U4a) is characterized by the presence of a communicating or non communicating functional contralateral horn. ${ }^{2,5}$ Since women with this condition are asymptomatic, the true incidence has not been yet determined. ${ }^{3}$ However, it has been reported that between $0.1 \%$ of the unselected population, 
unicornuate uterus is significantly more common in women with a history of miscarriage, miscarriage in association with infertility, and/or infertility alone. ${ }^{1,2}$ This malformation is associated with the presence of a rudimentary horn in 74$90 \%$ of cases. 1,6 Approximately, $25 \%$ of these horns are characterized by the presence of a cavity with functional endometrium, which does not communicate with the main cavity of the contralateral unicornuate uterus. ${ }^{6}$ We presented a case of unicornuate uterus with rudimentary cavity and non communicating horn.

\section{CASE}

A 32-year-old nulligravid woman was referred to the hospital with chief complaint of severe progressive worsening abdominal pain. She had been married for 1 year. Physical examination revealed normal vagina and cervix. Abdominal ultrasound revealed double uterus. Laboratory examination demonstrated hemoglobin of $14.8 \mathrm{~g} / \mathrm{dl}$, hematocrit of $36.5 \%$, white blood cell count of $7300 / \mathrm{mm}^{3}$, and Ca-125 of $17.41 \mathrm{U} / \mathrm{ml}$. Chest X-ray and ECG were normal. A month prior to laparotomy, a laparoscopy was done, and we found a unicornuate uterus with right rudimentary cavity and non communicating horn. Partial hysterectomy was performed to the right rudimentary uterus with hematometra. Both ovaries and the fallopian tubes were within normal limits.

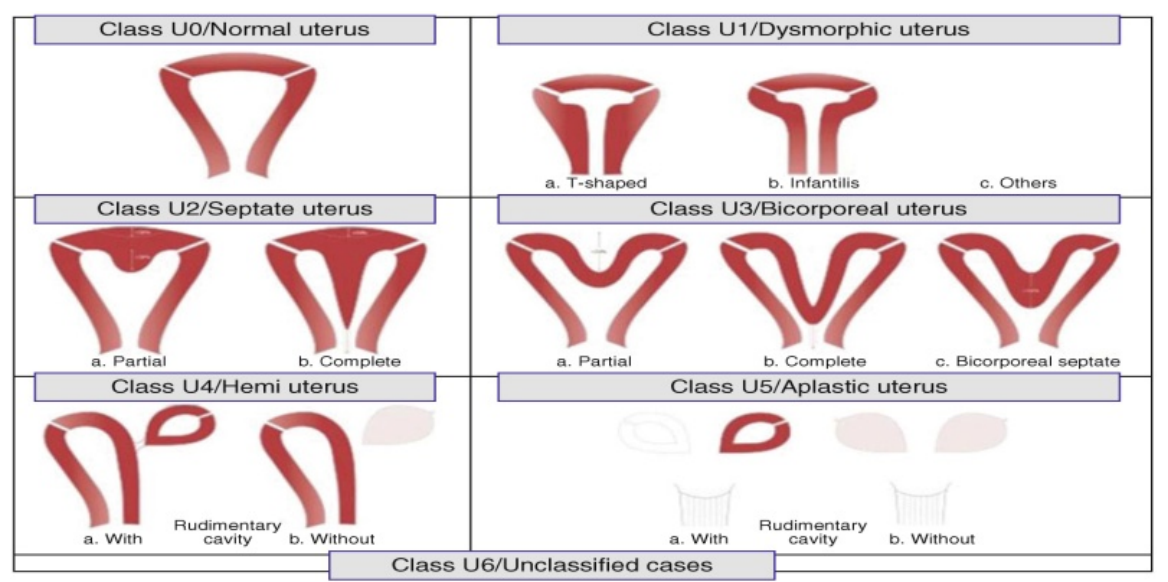

Figure 1. The ESHRE/ESGE classification of uterine anomalies (Adapted from Grimbizis, et al.) ${ }^{1,3}$
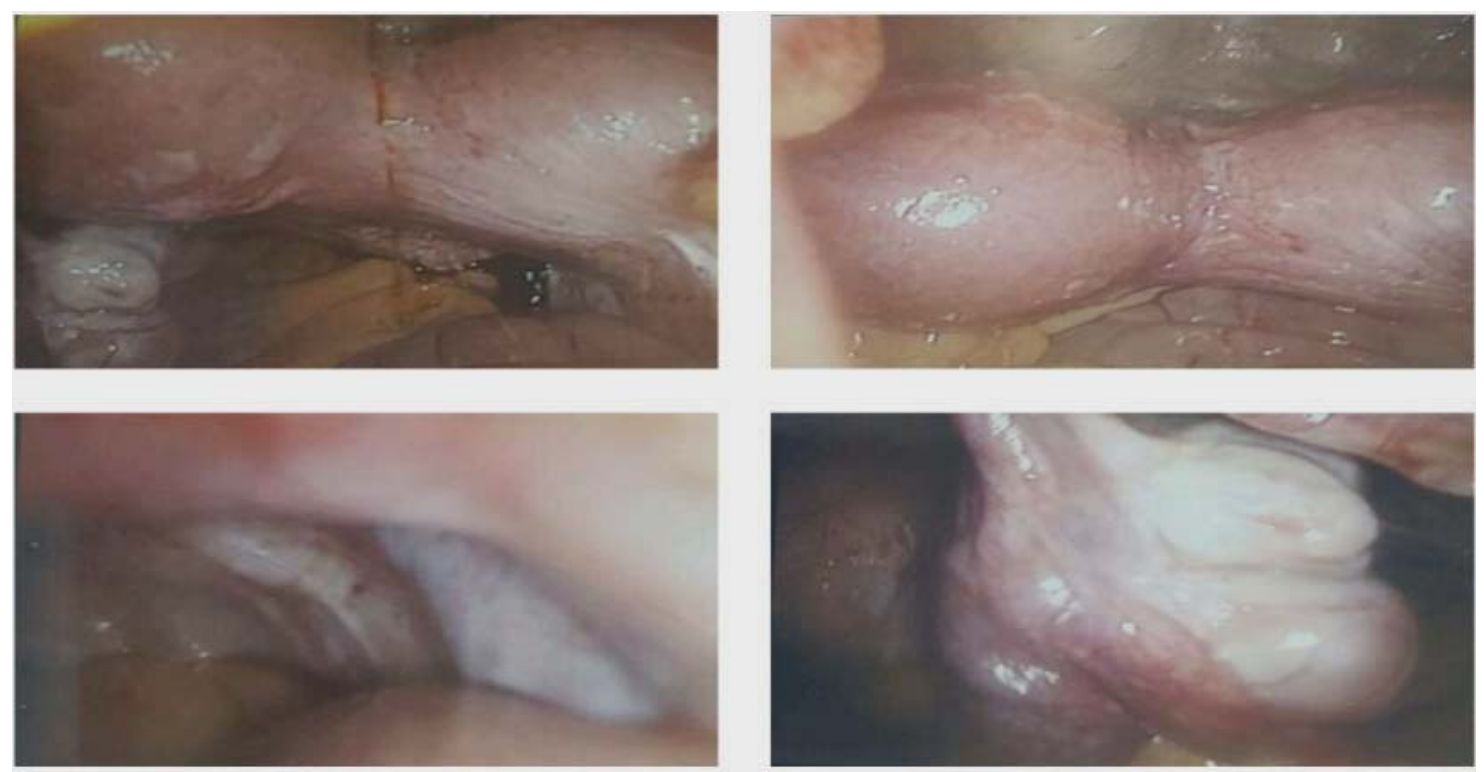

Figure 2. Show the topography between left uterus and right rudimentary uterus (Laparoscopic view) 


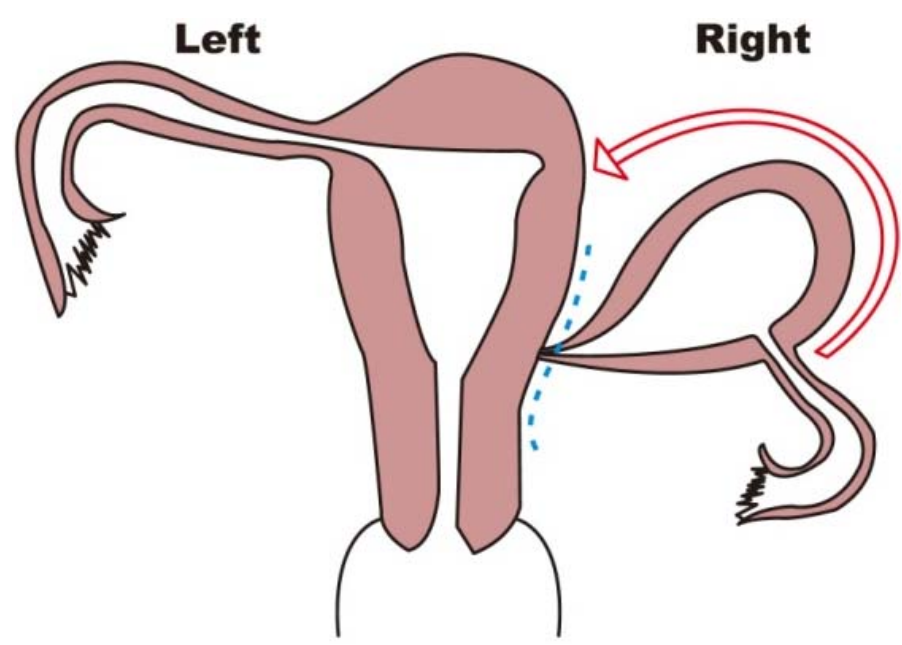

Figure 3. Schematic representation of hyterectomy
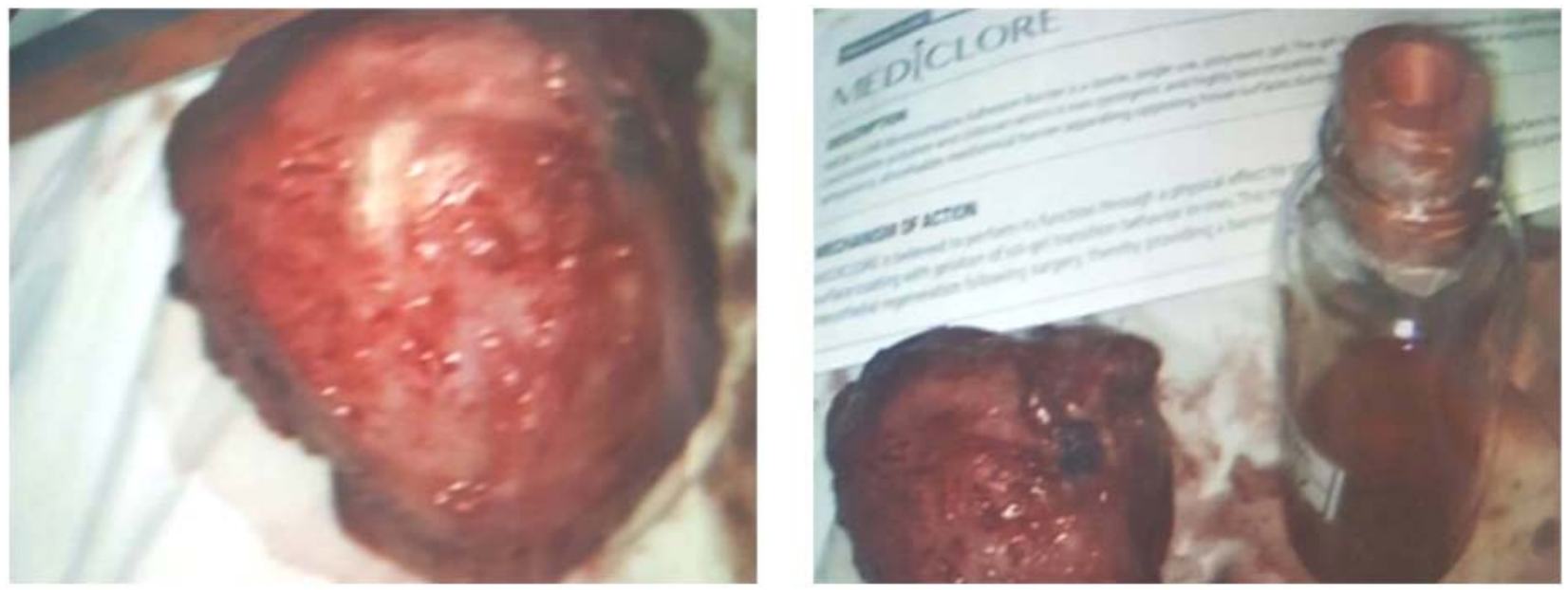

Figure 4. Partial hysterectomy perform to the right rudimentary uterus (Laparotomy)

\section{DISCUSSION}

Unicornuate uterus of the Mullerian duct is a congenital anomaly resulting from a rudimentary horn.1,2,3 The developmental anomaly is classified according to its relation with the uterine cavity. The pathogenesis of Mullerian duct abnormality has been well established, yet the etiology remains unknown. The etiologies are multifactorial, including genetic and environmental factor. The embryologic tendency of dominance of the rightsided unicornuate uterus remains unelucidated.

The true incidence of female congenital malformations is unknown. ${ }^{1}$ The use of diagnostic tools with different accuracie, the subjectivity in the criteria used for diagnosis and classification of the anomalies as well as the drawbacks of the existing classification systems represent the main biases for the actual burden. The recently introduced ESHRE/ESGE classification of female genital anomalies aims to provide a more suitable classification system for an accurate, clear, and simple categorization of female genital anomalies associated with the clinical management. ${ }^{4}$ Diagnosing these anatomical malformations is not an easy task; hysteroscopy, HSG and 2D-transvaginal ultrasound are suboptimal approaches because most of these tests do not allow evaluation of the external contour of the uterus. MRI has been reported to have a high accuracy rate in diagnosing unicornuate uterus. ${ }^{6}$ Unicornuate uterus can be found incidentally during gynecologic examination or because of abdominal pain as seen in our case.

One possible cause of abdominal pain in this patient is uterine distention due to blood accumu- 
lation in the noncommunicating cavity of the rudimentary horn (hematometra). ${ }^{1,6}$ Excision of the uterine horn without a functioning endometrium attached to the unicornuate uterus merely to enhance obstetric outcomes is not warranted. When there is no functioning endometrium, no intervention is warranted. However, if functioning endometrium is present, excision should be considered particulaly when complicated with hematometra. Surgical removal of the noncommunicating horn is commonly performed particularly on functional endometrium to prevent endometriosis and pregnancy within the horn. Hadisaputra, et al (2016) reported a successful pregnancy after histerectomy of bicorporeal uterus, delivering a healthy baby of 3260 grams. $^{7}$ In this case, removal of the functional cavity resulted in relief of abdominal pain.

\section{CONCLUSION}

This case was classified as class U4a - unicornuate uterus with a right-side rudimentary (functional cavity) and hematometra. It is associated with increased rate of preterm birth, fetal malpresentation and gestation in the rudimentary cavity. Surgical intervention is proven to be a successful approach in the treatment of this congenital Mullerian anomaly. Further investigation to assess whether the removal of rudimentary cavity of unicornuate uterus might increased the rate of successful pregnancy is required.

\section{REFERENCES}

1. Grimbizis GF, Campo R, Tarlatzis BC, Gordts S, et al. Female Genital Tract Congenital Malformation: Classification, Diagnosis, and Management. London: Springer. 2015; 1545.

2. Chan YY, Jayaprakasan K, Tan A, et al. Reproductive outcomes in women with congenital uterine anomalies: A systematic review. Ultrasound Obstet Gynecol. 2011; 38: 371-82.

3. Chan YY, Jayaprakasan K, Tan A, et al. The prevalence of congenital uterine anomalies in unselected and high risk populations: A systematic review. Hum Reprod Update. 2011; 17(6): 761-77.

4. Grimbizis GF, Gordts S, Sardo ADS, et al. The ESHRE/ESGE consensus on the classification of female genital tract congenital anomalies. Hum Reprod. 2013; 28: 2032-44.

5. Pados G, Tsolakidis D, Athanatos D, et al. Reproductive and obstetric outcome after laparoscopic excision of functional, non-communicating broadly attached rudimentary horn: A case series. Eur Obstet Gynecol Reprod Biol. 2014; 182: 33-7.

6. Vaz SA, Dotters K, Kuller JA. Diagnosis and Management of Congenital Uterine Anomalies in Pregnancy. Obstet Gynecol Surg. 2017; 72(3): 194-01.

7. Hadisaputra W, Pramayadi CT, Berguna JSN, et al. Successful Pregnancy After Hysterectomy in a Case of Bicorporeal Uterus With Hematometra. J Min Invasive. Gynecol. 2016; 23(6): 853-4. 